\title{
Advances in Effect of Germanium or Germanium Compounds on Animals-A Review
}

\author{
Lingjun Li', Tao Ruan1, Yingnan Lyu' ${ }^{2}$, Bangyuan $\mathrm{Wu}^{1,3^{*}}$ \\ ${ }^{1}$ College of Life Science, China West Normal University, Nanchong, China \\ ${ }^{2}$ Department of Microbiology and Immunology, National University of Singapore, Singapore \\ ${ }^{3}$ Key Laboratory of Southwest China Wildlife Resources Conservation (China West Normal University), Ministry of Education, \\ Nanchong, China \\ Email: ^wubangyuan2008@163.com, *wby2008@cwnu.edu.cn
}

How to cite this paper: Li, L.J., Ruan, T., Lyu, Y. and Wu, B.Y. (2017) Advances in Effect of Germanium or Germanium Compounds on Animals-A Review. Journal of Biosciences and Medicines, 5, 56-73. https://doi.org/10.4236/jbm.2017.57006

Received: June 19, 2017

Accepted: July 22, 2017

Published: July 25, 2017

Copyright ( 92017 by authors and Scientific Research Publishing Inc. This work is licensed under the Creative Commons Attribution International License (CC BY 4.0).

http://creativecommons.org/licenses/by/4.0/ (c) (i) Open Access

\begin{abstract}
An increasing number of researches have been focused on the relationship between trace elements and animal health. Germanium, as a widely used trace element, exists ubiquitously as germanium or germanium compounds in the living environment of human and animals, and plays important roles in animal production or health. With the intensive study of the physiological function of germanium and its compounds, the effects of germanium on animal physiological functions and health have been gradually confirmed. In this review, we discuss the metabolic distribution, physiological characteristics, biological functions, germanium deficiency and germanium toxicity. Furthermore, we focus on the effects of germanium or germanium compounds on the immunity of animals. It is concluded that germanium or germanium compounds not only has positive effect but also has negative effect on animals. This review aims to provide a reference for the future research or application of the germanium or germanium compounds on animals or human beings.
\end{abstract}

\section{Keywords}

Germanium, Germanium Compounds, Physiological Function, Toxicity, Immunity

\section{Introduction}

Germanium (Ge) was first discovered and named by the German chemist Winkler in 1886, and then it has been found and detected as a trace element from the plants and animals. After 1960s, the biological function of germanium and mechanism of interaction with body have become the hot topics in scientific research. In the past twenty years, as a semiconductor material, germanium was 
widely used in the electronic fields. Germanium also possesses many significant biological functions, such as antibacterial, antiviral, anti-inflammatory, anticancer or antitumor functions, and elimination of the free radicals, prevention of cell aging, regulation of immunity and so on. Nowadays, some food and medical materials containing germanium have been found to have special health effects. Therefore, the germanium or germanium compounds (especially the organic form) is known as "a patron saint of the human health". Therefore, germanium has been successfully applied in medical and healthcare fields, and now widely used in animal husbandry. This review aims to discuss the application of germanium in animals from the aspects of metabolic distribution, physiological characteristics, biological functions, germanium deficiency or toxicity, and the influence of germanium on animal immunity, as showed in below Chart 1 .

\section{Distribution, Absorption and Metabolism of Germanium}

\subsection{Distribution in the Animal Tissues and Organs}

Germanium is widely distributed throughout the body and is not selectively retained in any tissue [1]. The concentration of germanium is generally very low in animal tissues or organs, and is different in different tissues and organs: from high to low in kidney, liver, lung, stomach, muscle, heart and brain [2]. Germanium can also be found in many enzymes of the body, such as guaninase, cytochrome oxidase, carbonic anhydrase, and in some other subcellular organelles including the cell wall, mitochondria and chromosomes [3].

\subsection{Absorption and Metabolism}

The contact of animals to germanium is mainly through drinking water, food intake, respiration, intramuscular or intraperitoneal injection. Animal experimental results showed that germanium compounds, both inorganic and organic, are rapidly and almost completely absorbed into the lungs and gastrointestinal tract mucosa [2] [4]. The germanium and plasma proteins can be transported in an unbound state if they are injected into the blood directly, and are excreted by both the kidney and the gastrointestinal tract, where the kidney is the chief excretory organ (80\% versus 13\%) [5] [6] [7].

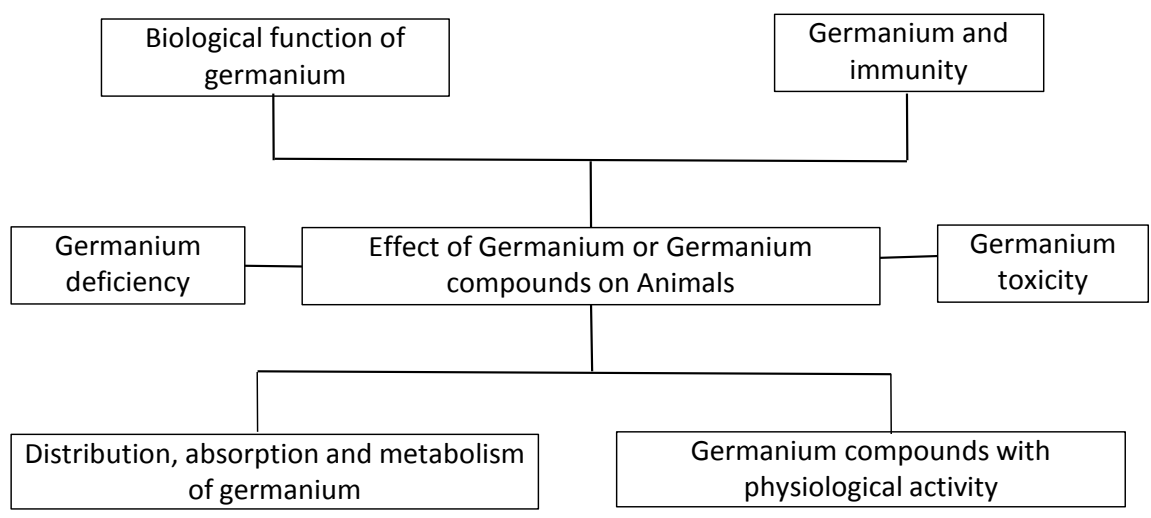

Chart 1. Effect of germanium or germanium compounds on animals. 


\section{Germanium Compounds with Physiological Activity}

There are usually two forms of germanium compounds, which are inorganogermanium and organogermanium. Inorganogermanium is very toxic to organisms, which is banned strictly in use, and the organogermanium is beneficial to human and animal health, but the accuracy of dosage used should be monitored carefully. The organogermanium sesquioxide and its derivatives are the most studied organogermanium compounds. In recent years, drugs containing organogermanium compounds, such as 2-Carboxyethyl germanium sesquioxide (Gee-132), spirogermanium, and germanium-lactate-citrate, have been widely used in the treatment of AIDS and cancer [8].

\subsection{2-Carboxyethyl Germanium Sesquioxide (Ge-132)}

Ge-132 (with structural formula $\mathrm{GeCH}_{2} \mathrm{CH}_{2} \mathrm{COOH}_{2} \mathrm{O}_{3}$ ), is an organogermanium compound with some important biological functions, such as antioxidant effect and immunoregulatory activities [9] [10]. Ge-132 is also an immune stimulant with broad spectrum of anti-tumor activities [11] [12]. Subsequently, many Ge132 derivatives and analogues were synthesized, such as organogermanium sesquioxide and sesquisulfide, which all connect with molecules with good efficacy to increase the efficiency of the drugs. Ge-132 is widely used as it belongs to the non-toxic active substances, and the acute toxicity or chronic toxicity is very low [10]. Consequently, it has been used as an ingredient in health foods and supplements in many countries nowadays [13].

\subsection{Spirogermanium Compounds}

Spirogermanium is a new metallic investigational anticancer drug, which is synthesized by Rice et al. in 1974. Spirogermanium is a metal-containing compound reported to have antitumor, antiarthritic, antimalarial and immunoregulatory activities [5] [14] [15]. Spirogermanium compounds have pivotal biological functions, including lymphocyte atrophy or degeneration, and nucleus fragmentation, and they play a key role in cell lysis by inhibiting protein synthesis [16]. As a novel heterocyclic anticancer drug, spirogermanium compounds exert anti-cancer activity by inhibiting the synthesis of DNA or RNA and enhancing the immune responses [17] [18] [19]. Nevertheless, excess dose of the spirogermanium compounds have toxic effects on lymphoid tissues, bone marrow, liver, central nervous system and red blood cells (RBCs) [20].

\subsection{Amino Acid Germanium}

Amino acid germanium, is characterized by the low toxicity and a wide range of functions, such as anticancer, anti-hypertension and anti-inflammation activities [21]. Germanium histidine complex exhibits very strong cytotoxic effects on the ehrlich ascites carcinoma (EAC) cells [22] [23]. Methionine germanium has positive effects on immune promotion and antitumor [24] [25]. Alanine germanium also has the function of anti-tumor activity and immuno-enhancement, which 
can prolong the survival time of mice transplanted with $\mathrm{H} 22$ hepatoma and inhibit the growth of S180 sarcoma obviously [26]. Gao et al. (1990) and Zhao et al. (1990) [27] [28] reported that amino acid germanium oxide (AGO) also played important role in anti-tumor activity, while germanium arginine complex exhibited a poor effect on tumor cells [22].

\subsection{Lactic Acid-Citrate Germanium}

Lactic acid-citrate germanium has an inhibiting effect on lipid peroxidation [29], which can enhance the immune function as an "immunostimulant" [30] [31]. Besides, it has an obvious anti-tumor effect [32]. However, long term and overdose intake of germanium lactate-citrate (a cumulative dose of $32.1 \mathrm{~g}$ germanium) could lead to damages to organs or tissues [33].

\subsection{Other Germanium Compounds}

In additional to the above-mentioned germanium compounds, some other new germanium compounds with biological functions have been synthesized and applied in a wide spectrum of fields. For instance, p-dimethylaminophenylgermanium sesquioxide (Ge-162) has the effect of inhibiting the growth of the tumor [34]. Germanium yeast (Ge-168) has important nutritional values and plays an important part in inhibitingthe hepatic tumor induced by aflatoxin B1 [35] [36]. In addition, novel organogermanium sulfide compound, organogermanium sesquioxide and sulfide, Ge-132 amide derivatives, germanium amino acid derivatives, $\alpha$-phenyl- $\beta$-(N-Amido) ethyl germanium semi oxide and alkyl thio germanium compound [37], are being synthesized and applied in an increasingly large scale in animal production. Studying all of the germanium compounds pave the way for the search of more effective anticancer drugs containing germanium, and lay a foundation for the studying the biological functions of the germanium or germanium compounds.

\section{Biological Function of Germanium}

\subsection{Antitumor Function of the Germanium Compounds}

Organogermanium compounds have some advantages, such as low toxicity and antitumor activity, which suggest a great potential in the prevention and treatment of cancer and adjuvant radiotherapy. Their low bone marrow toxicity also make them great choices for chemotherapy. The in vitro and in vivo experiments showed that most of the organogermanium or polyacid derivatives could inhibit tumor cells growth and has a dose dependency [38] [39] [40] [41] [42]. Ge-132 has a significant inhibitory effect on the occurrence and development of the tumor induced by broiler Marek's disease virus (MDV) [43]. Germanium dioxide $\left(\mathrm{GeO}_{2}\right)$ can inhibit the formation of tumor by enhancing the communication of the intercellular connection [44]. Caffie acid germanium can inhibit the growth of the U14 tumor in mice and induce the apoptosis of U14 tumor cells [45]. 


\subsection{Participation in the Metabolism of Oxygen in Vivo}

There are many Ge-O (germanium and oxygen) bonds in organogermanium, which have strong ability of oxidative dehydrogenation. Germanium enters the organism and binds to hemoglobin, thereby ensuring normal cellular aerobic metabolism [46]. In addition, the germanium compounds can capture the hydrogen ions and other harmful ions in the metabolites, and play a role in purifying blood at different degrees [47].

\subsection{Antioxidant and Scavenging the Free Radicals}

Germanium can scavenge the free radicals and enhance the body's antioxidant capacity. As a result, organogermanium can reduce the lipid peroxidation, protect the cell membrane from injury, and reduce the lipid peroxide level in plasma, liver or brain tissues [48] [49] [50] [51]. Ge-132 can significantly increase the glutathione peroxidase (GSH-Px) and superoxide dismutase (SOD) activity in broilers [52] [53], and reduce the amount of free radicals in liver and kidney of rats [54]. In addition, the in vitro studies have also found that G-132 is able to scavenge reactive oxygen species and prevent reactive oxygen species from inducing injury to cells [55] [56]. Appropriate concentration of lactic acid citrate germanium can increase the levels of reduced glutathione (GSH) in rat hepatocytes [57]. On one hand, the mechanisms of the organogermanium antioxidation and free radical scavenging consist the increase of SOD and GSH-Px activity in blood as well as the reduction of serum lipid peroxide (LPO). On the other hand, due to the unique electronic layer structure of organogermanium, the outer electrons can become the free electronic, which could also scavenge the free radicals eventually [58].

\subsection{Regulation of the Lipid Metabolism}

Germanium or germanium compounds can regulate and affect the lipid metabolism. For instance, organic and inorganic germanium may affect the lipid metabolism in chicken and reduce the content of cholesterol in egg yolk [59]. Moreover, with the increase of germanium content in blood and egg, the total blood lipid and triglyceride content are decreased, and the cholesterol content in blood and yolk decrease [60] [61]. It was found that the contents of total fat, glycerin, triglycerides and cholesterol decrease to different degrees with the addition of Ge-132 to the diet [50] [62].

\subsection{Stimulating the Hematopoietic Function}

Germanium can increase the number of red blood cells (RBCs) and hemoglobin $(\mathrm{Hb})$ in the blood system and stimulate the formation of platelet generating cells (PGCs), thus stimulating the hematopoiesis [63]. For example, germaniumoxide $\left(\mathrm{GeO}_{2}\right)$ can promote the generation of $\mathrm{RBCs}$ and has a certain therapeutic effect on anemia [64] [65]. In addition, Ge-132 can increase the expression of cell stimulating factor IL-3 in the multifunctional hematopoietic stem cells (HSCs) and involve in the regulation of the differentiation and proliferation of multifunc- 
tional hematopoietic stem cells (MHSCs) and the progenitor cells, thus regulating the hematopoietic function in the body [66] [67]. Spirogermanium may promote the maintenance of normal marrow cells in bearing [68]. The main reason for germanium-stimulated hematopoiesis is that germanium could increase blood absorption of oxygen, which can be combined with blood cells and absorbed directly by blood vessels, and then promote the generation of RBCs [69].

\subsection{Inhibit Bacterial Growth}

Germanium has a strong antibacterial effect. Aso et al. (1982) [70] and Arimori et al. (1981) [71] found that germanium inhibited the growth and propagation of Fusarium, Escherichia coli, Staphylococcus aureus and Bacillus subtilis. The growth of lactic acid bacteria was inhibited by organic germanium compoundGe-132 [72]. Mrema et al. (1983) [73] found that spirogermanium was an antimalarial drug with an entirely novel structure that was active in resistant strains. Tributylgermanium acetate has antimicrobial activities, but the main active substances that inhibit fungi are the ethyl and propyl germanium compounds, and the longer chains lead to the more antibacterial activities [74] [75] [76] [77].

\subsection{Improve the Growth and Production Performance}

Germanium can promote the growth of animals by increasing the content of iodine, including triiodothyronine (T3) and tetraiodothyroxine (T4) content, and enhancing the metabolic function of organisms. Inorganogermanium (such as $\mathrm{GeO}_{2}$ ) can obviously promote the growth of chicken, and increase the feed reward and slaughter rate [78] [79] [80]. Ge-132 is also useful for increasing the body weight of young chicken [81] [82]. Moreover, Ge-132 could significantly improve the laying rate, the rate of fertilized eggs and the hatching rate of laying hens [60] [61] and improve egg quality [83]. In addition, organogermanium has certain effects on the reproductive endocrine of animals, and is involved in the regulation of the endocrine system. Other germanium compounds, such as germanium colloid or germanium biotite, also have the positive effects on the animal growth [84] [85].

\subsection{Other Physiological Functions of Germanium}

Except for what was mentioned above, germanium possesses many other biological functions. It has been proven that germanium can prevent pigmentation and inhibit the production of melanocytes. Ge-132, for example, can reduce the synthesis of melanocytes by reducing the number of organelles, increasing the apoptosis, and decreasing the tyrosinase activity [86]. In addition, Ge-132 can prevent cataract by dissolving glycated proteins and increasing the activity of $\mathrm{Na}^{+}-\mathrm{K}^{+}$-ATP enzymes [87] [88] [89] [90] [91]. Amino acid germanium oxide or organogermanium-Ge-401 can extend the average lifespanand the maximum lifespan of the fruit fly [92]. Ge-132 can inhibit the development of liver necrosis and the increase of serum glutamic pyruvic transaminase (SGPT) which induced by carbon tetrachloride in mice, and then play a key role in protecting the liver 
[93]. Organogermanium can improve the ability of animals to survive hypoxia and extend the life of animals in hypoxia [54]. In human, Ge-132 can significantly reduce the level of parathyroid hormone in serum, prevent and treat age-related osteoporosis [94] [95], and could be the prevention of old age amyloidosis [96] [97]. The oxide of germanium could inhibit the genotoxicity of cadmium chloride as well [98].

\section{Germanium Deficiency}

There is no known biologic requirements for germanium, germanates, or any organogermanium compound. Germanium deficiency has not been demonstrated in any animals, but some evidences suggest that certain concentration of germanium compounds can promote animal growth, digestion and absorption of the food [99] [100]. Further studies are required to clarify whether germanium deficiency can affect the biological functions, such as growth and development, or digestion and absorption function. In addition, it has been reported that taste loss is associated with the germanium deficiency [101].

\section{Germanium Toxicity}

It has been reported that excessive or long-term exposure to germanium has toxicological effects and damages on the kidneys [102] [103], nervous system [104], and lungs [105] [106]. The toxicity of inorganogermanium is greater than that of organogermanium.

Acute poisoning of germanium can lead to changes in depression, hypothermia, diarrhea, skin cyanosis, pulmonary edema, ascites, edema and swelling of parenchymal cells of the liver, kidney or other organs [107]. Arts et al. (1994) [108] found that the toxicity of high-concentration germanium oxide on mice was greater than that of low concentration, indicating that the impact of germanium oxide on animals was dose-dependent.

Though organogermanium has important physiological functions, improper dosage or long-term exposure may also be toxic to animals. Spirogermanium can have obvious toxic effects on the liver, kidney and hematopoietic system [105]. Other organogermanium compounds such as Ge-132 and Ge-201 can cause nausea, vomiting, diarrhea, and even liver and kidney damage and tremors, and can interfere with phosphorus and calcium metabolism [10] [47].

The above content has been summarized in Table 1 .

\section{Germanium and Immunity}

A large number of reports have pointed out that germanium or germanium compounds have different effects on immune organs, immune cells or other immune factors.

\subsection{Effects of Germanium on the Growth and Development of Immune Organs}

The effects of organogermanium and inorganogermanium on the development 
Table 1. Positive and negative effects of gernamium or germanium compounds on animals.

\begin{tabular}{cllll}
\hline $\begin{array}{c}\text { Metabolic } \\
\text { distribution }\end{array}$ & $\begin{array}{l}\text { Germanium compounds with } \\
\text { physiological characteristics }\end{array}$ & \multicolumn{1}{c}{ Biological functions } & $\begin{array}{c}\text { Germanium } \\
\text { deficiency }\end{array}$ & Germanium toxicity \\
\hline Kidney & & Antitumor function & Kidneys \\
Liver & & Participation in metabolism of oxygen & Liver \\
Lung & Ge-132 & Antioxidant and scavenging the free radicals & Lungs \\
Stomach & Spirogermanium compounds & Regulation of the lipid metabolism & No biologic \\
Muscle & Amino acid germanium Lactic & Stimulating the hematopoietic function & Hematopoietic system \\
for germanium & Nervous system \\
Brain & Aacid-citrate germanium & Inhibit bacterial growth & Phosphorus and calcium \\
metabolism
\end{tabular}

of immune organs in animals remain controversial, some reports have pointed out that germanium or germanium compounds could influence the development of immune organs, while others not. Barley containing rich germanium can increase the weight of immune organs (spleen) [109]. The immune organs (thymus, bursa and spleen index) gain weight more quickly after hatching with the breeding egg containing more germanium [110]. Germanium citrate significantly increased the weight of immune organs (thymus and spleen) of Kunming mice [31]. However, Niu et al. (2001) [111] reported that the additional organogermanium had no significant effects on the growth of immune organs in broilers at different stages, and the organogermanium Ge-201 had no significant effect on thymus and spleen index in mice [112] [113]. It can be seen that the effects of germanium or germanium compounds on the growth of immune organs are still inconsistent and further study is required.

\subsection{Effects of Germanium on Nonspecific Immunity}

Nonspecific immunity, also known as innate immunity, mainly involves phagocytes, killer cells, and dendritic cells. The phagocytosis rate, phagocytosis index and phagocytosis of macrophage in mice can be significantly enahnced by the administration of appropriate doses of organogermanium or inorganogermanium [114] [115] [116] [117]. In addition, barley with rich amount of germanium could significantly improve the phagocytosis of peritoneal macrophages in healthy Kunming mice (male) [109]. Studies have revealed that Ge-132 activated immune cells, inducing the activation of NK cells and macrophages [70]. Organogermanium Ge-201 by intravenous injection also significantly increased carbon clearance rate, phagocytosis percentage and phagocytic index of mice [113]. Moreover, germanium biotite can increase the lysozyme activity [118].

\subsection{Effects of Germanium on Humoral Immunity}

Humoral immunity is achieved by production of antibodies by B cells, which then perform the protective function to the organism. Germanium affects the 
humoral immunity mainly through the actions on antibodies or antibodies producing cells. An appropriate amount of germanium could significantly increase the amount of antibodies against chicken red cells and the number of antibody producing cells in mice [109]. Citrate germanium can significantly boost antibodies level against serum hemolysin of Kunming mice [31]. Organogermanium Ge-132 can significantly enhance humoral immune response in mice [119]. Organogermanium Ge-401 can increase the ability of murine B lymphocytes in antibody production [120]. Tang et al. (1996) reported that the serum antibody and the levels of $\lg G$ and $\lg M$ increased significantly in offspring of chickens when the breeding chicken of parent generation consume the germanium diet. Ge yeast can also increase the production of antibodies by B cells [121]. High level of IgG and IgA titers in serum and saliva were observed in the germanium biotite treated group [118].

\subsection{Effects of Germanium on Cellular Immunity}

T cells are the major cells involved in cellular immunity and the effect of germanium on cellular immunity is mainly through $\mathrm{T}$ cells. Some studies indicated that Ge-132 could significantly contribute to the higher T lymphocyte transformation rate in chickens inoculated with Marek's virus [43] or experimental murine ascites tumors [122]. Besides, Ge-132 can not only significantly enhance the cytotoxicity of NK cells to target cells [115], but also increase the ratio of total $\mathrm{T}$ lymphocyte subsets $\left(\mathrm{CD}^{+}, \mathrm{CD}^{+}, \mathrm{CD}^{+}\right)$and ratio of $\mathrm{CD}^{+} / \mathrm{CD}^{+}$[123] [124]. All discussion above suggests that Ge-132 are essential for enhancing cellular immune function of animals. The germanium biotite can increase percentage of $\mathrm{CD}^{+}$lymphocytes and major histocompatibility complex (MHC) $\mathrm{I}^{+} \mathrm{II}^{+}$cells in peripheral blood mononuclear cells (PBMCs), responding to stimulation by ConA [118].

\subsection{Effects of Germanium on Cytokines}

Cytokines are synthesized and secreted by immune cells (such as monocytes, macrophages, T cells, B cells, and NK cells etc.) and some non-immune cells (endothelial cells, epidermal cells, and fibroblasts etc.). They are small molecular proteins with a wide range of biological significances. Organogermanium has been reported to induce cellular production of interleukin (IL) and interferon (IFN) [125]. For instance, Ge-132, has a strong activity on inducing the generation of exogenous IFN in chickens [116] [126] [127]. The propagermanium can improve hepatitis through reducing the gereration of TNF- $\alpha$ [128]. The levels of IFN- $\gamma$, IL- $1 \alpha$, IL- $1 \beta$, and IL-4 gene expression were also significantly increased after treated with germanium biotite [118].

Therefore, the effect of the germanium on the immunity mainly involved in the growth and development of immune organs, immune cells (such as killer cells, dendritic cells, NK cells and macrophages, $\mathrm{T}$ cell and B cell and so on), production of antibodies or immunoglobulins, and cytokines. The mechanisms may be refer to the oxidative function, because the germanium participate in the 
regulation of the lipid metabolism or oxygen metabolismin vivo. In addition, we speculate that the germanium could affect some enzymes activities or subcellular organelles of immune organs or immune cells, and then pose direct or indirect effect on immune system. But the exact mechanisms of the effect of germanium or germanium compounds on immunity should be clarified in the future study.

\section{Research Perspectives}

Organogermanium compounds have many biological activities and pharmacological effects, and the investigation of this kind of compounds requires more attention. However, germanium has not been yet proven to be a necessary trace element in the animal body and germanium deficiency has not been reported in any animal at present. Therefore, it might be feasible to develop and apply organogermanium as a new type of feed additive, but definitely with further studies. In the future, we should focus on the investigation of the effect of germanium on the development of immune organs in broilers and the mechanism of action from the aspects of histology and histochemistry. In addition, the study of germanium and germanium compounds toxicity needs to be further studied. It remains to be resolved and researched on how to reduce the toxicity of germanium and germanium compounds and exert their anti-tumor effects as the new anticancer drugs.

\section{Acknowledgements}

The study was supported by the program for the scientific research project of China West Normal University (416370).

\section{References}

[1] Stewart, J.H. and Donald V.L. (2000) Germanium, Tin, and Copper. Patty's Toxicology. John Wiley \& Sons, Inc., 51-54. https://doi.org/10.1002/0471435139.tox033

[2] Keith, L.S., Faroon, O.M., Maples-Reynolds, N. and Fowler, B.A. (2015) Germanium-Handbook on the Toxicology of Metals. Chapter 37. Handbook on the Toxicology of Metals, 4th Edition, 799-816. https://doi.org/10.1016/B978-0-444-59453-2.00037-8

[3] Song, C.L., Ji, C. and Jing, X.D. (2005) Advance in Physical and Chemical Properties of Germanium and Nutrition Functions in Animals. Chinese Journal of Animal Science, 41, 64-66.

[4] Rosenfeld, G. (1954) Studies of the Metabolism of Germanium. Archives of Biochemistry and Biophysics, 48, 84-94. https://doi.org/10.1016/0003-9861(54)90308-2

[5] Dimartino, M.J., Lee, J.C., Badger, A.M., Muirhead, K.A., Mirabelli, C.K. and Hanna, N. (1986) Antiarthritic and Immunoregulatory Activity of Spirogermanium. Journal of Pharmacology \& Experimental Therapeutics, 236, 103-110.

[6] Burley, R.W., Evans, A.J. and Pearson, J.A. (1993) Molecular Aspects of the Synthesis and Deposition of Hens' Egg Yolk with Special Reference to Low Density Lipoprotein. Poultry science, 72, 850-855. https://doi.org/10.3382/ps.0720850

[7] Kobayashi, A. and Ogra, Y. (2009) Metabolism of Tellurium, Antimony and Germanium Simultaneously Administered to Rats. The Journal of Toxicological Sciences, 34, 295-303. https://doi.org/10.2131/jts.34.295 
[8] Krystek, P. and Ritsema, R. (2004) Analytical Product Study of GermaniumContaining Medicine by Different ICP-MS Applications. Journal of Trace Elements in Medicine and Biology, 18, 9-16. https://doi.org/10.1016/j.jtemb.2004.04.003

[9] Kim, E., Jeon, Y., Kim, D.Y., Lee, E. and Hyun, S.H. (2015) Antioxidative Effect of Carboxyethylgermanium Sesquioxide (Ge-132) on Ivm of Porcine Oocytes and Subsequent Embryonic Development after Parthenogenetic Activation and IVF. Theriogenology, 84, 226-236. https://doi.org/10.1016/j.theriogenology.2015.03.006

[10] Nakada, Y., Kosaka, T., Kuwabara, M., Tanaka, S., Sato, K. and Koide, F. (1993) Effects of 2-Carboxythylgerumanium Sesquioxide (Ge-132) as an Immunological Modifier of Post-Surgical Immunosuppression in Dogs. Journal of Veterinary Medical Science, 55, 795-799. https://doi.org/10.1292/jvms.55.795

[11] Ikemoto, K., Kobayashi, M., Fukumoto, T., Morimatsu, M., Pollard, R.B. and Suzuki, F. (1996) 2-Carboxyethylgermanium Sesquioxide, a Synthetic Organogermanium Compound, as an Inducer of Contrasuppressor T Cells. Experientia, 52, 159 166. https://doi.org/10.1007/BF01923363

[12] Suzuki, F., Brutkiewicz, R.R. and Pollard, R.B. (1986) Cooperation of Lymphokine(s) and Macrophages in Expression of Antitumor Activity of Carboxyethylgermanium Sesquioxide (Ge-132). Anticancer Research, 6, 177-182.

[13] Nakamura, T., Nagura, T., Sato, K. and Ohnishi, M. (2012) Evaluation of the Effects of Dietary Organic Germanium, Ge-132, and Raffinose Supplementation on Caecal Flora in Rats. Bioscience of Microbiota Food \& Health, 31, 37-45. https://doi.org/10.12938/bmfh.31.37

[14] Badger, A.M., Schwartz, D.A., Picker, D.H., Dorman, J.W., Bradley, F.C., Cheeseman, E.N., Dimartino, M.J., Hanna, N. and Mirabelli, C.K. (1991) Cheminform Abstract: Antiarthritic and Suppressor Cell Inducing Activity of Azaspiranes: Structure-Function Relationships of a Novel Class of Immunomodulatory Agents. Journal of Medicinal Chemistry, 22, 2963-2970.

[15] Badger, A.M. and DiMartino, M.J. (1988) Immunomodulatory Activity and NonSpecific Suppressor Cell Generation by Spirogermanium in Murine and Rat Models of Cell-Mediated Immunity. Immunopharmacology, 16, 33-43. https://doi.org/10.1016/0162-3109(88)90048-3

[16] Lukevics, E. and Ignatovich, L. (2003) Biological Activity of Organogermanium Compounds. Cheminform, 34, 279-295. https://doi.org/10.1002/chin.200345272

[17] Badger, A.M., Mirabelli, C.K. and Dimartino, M. (1985) Generation of Suppressor Cells in Normal Rats by Treatment with Spirogermanium, a Novel Heterocyclic Anticancer Drug. Immunopharmacology, 10, 201-207. https://doi.org/10.1016/0162-3109(85)90026-8

[18] Badger, A.M., Dimartino, M.J., Schmitt, T.C., Swift, B.A. and Mirabelli, C.K. (1987) Suppressor Cell Induction by the Anticancer Drug Spirogermanium. International Journal of Immunopharmacology, 9, 621-630. https://doi.org/10.1016/0192-0561(87)90129-9

[19] Hill, B.T. and Whelan, R.D. (1986) Spirogermanium-A Novel Antitumour Agent Expressing a Lack of Cross-Resistance in Vitro with a Range of 'Standard' Antitumour Drugs. Investigational New Drugs, 4, 359-365. https://doi.org/10.1007/BF00173508

[20] Schauss, A.G. (1991) Nephrotoxicity and Neurotoxicity in Humans from Organogermanium Compounds and Germanium Dioxide. Biological Trace Element Research, 29, 267-280.

[21] Lin, H., Wei, P.J., Gu, P.K. and Jin, Z.G. (1994) Protective Effect of GermaniumAminoacid on Rat Myocardial Cells Inculture to Oxygen and. Journal of Shanghai 
Second Medical University, 8, 62-68.

[22] Ismail, D.A. and Noaman, E. (2007) Synthesis and Antitumour Activity of Four Germanium Amino Acid Complexes. Egyptian Journal of Chemistry, 50, 29-37.

[23] Wang, R., Shi, P., Hu, B., Shen, Y., Wang, Z. and Li, C. (1998) Radiosensitizing Effects of Amino-Acid Germanium Compounds on Tumor Radiotherapy. Trace Elementsence, 5, 42-44.

[24] Chen, H.Z., Sun, C., Yu, A.Y. and Jin, Z.J. (1990) Antitumor Effect of Lysine Germanium. Proceedings of Academic Conference on Nutrition and Oncology of China Nutrition Society.

[25] Chen, H.Z., Sun, C., Yu, A.Y. and Jin, Z.J. (1990) The Promotional Effect of Lysine Germanium on Immune Function. Proceedings of Academic Conference on Nutrition and Oncology of China Nutrition Society.

[26] Ge, X.M., Zhao, F.J., Guo, J.S., Cheng, H.Z., Zhu, P.M. and Ji, Y.S. (1994) Antitumor Activity and Immunological Effect of Alanine-Germanium. Journal of Preventive Medicine of Chinese People's Liberation Army, 12, 341-344.

[27] Gao, S.Y. (1990) Clinical Application of the Amino Acid Germanium Oxide. Studies of Trace Elements and Health, 3, 2.

[28] Zhao, F.J., Guo, J.S., Ji, Y.S., Nie, Z., Chen, H.Z. and Sun, W. (1990) Research of the Anticancer Activity of the Amino Acid Germanium Oxide (AGO-GA). Proceedings of Academic Conference on Nutrition and Oncology of China Nutrition Society.

[29] Zheng, H.P. (2011) Physiological Function of Organic Germanium and Its Application in Food. Studies of Trace Elements and Health, 28, 65-67.

[30] Hess, B., Raisin, J., Zimmermann, A., Horber, F., Bajo, S., Wyttenbach, A. and Jaeger, P. (1993) Tubulointerstitial Nephropathy Persisting 20 Months after Discontinuation of Chronic Intake of Germanium Lactate Citrate. American Journal of Kidney Diseases, 21, 548-552. https://doi.org/10.1016/S0272-6386(12)80403-3

[31] Lu, S.L., Tang, J.X. and Deng, L.S. (1997) Effects of Germanium Citrate on the Immunogenic Function of Mice. Guangdong Trace Elements Science, 4, 21-23.

[32] Lu, S.L., Zhang, G.L., Zhong, H.L. and Ren, G.Y. (1998) An Experimental Study on Antitumor Effect of Germanium Citrate. Guangdong Trace Elements Science, 5, 4446.

[33] Van, S.J.I., Stricker, B.H., Schipper, M.E., Bruijn, W., Smet, P.A. and Esseveld, M.R. (1991) Toxic Damage of Kidney, Liver and Muscle Attributed to the Administration of Germanium-Lactate-Citrate. Nederlands Tijdschrift Voor Geneeskunde, 135, 1134-1137.

[34] Zhang, S.G., Ni, J.Z. and Nie, Y.X. (1990) The Synthetic Properties and Anticancer Activity of Ge-162 (Abstract). Studies of Trace Elements and Health, 3, 11.

[35] Tang, B.H., Mo, Z.S. and Huang, S.D. (1994) Studies on Germanium Yeast. Journal of Preventive Medicine of Chinese People's Liberation Army, 12, 179-183.

[36] Liu, Y.F., Shi, J.Y., Tang, R.H. and Zhu, H.T. (1984) The Promotional Effect of Germanium on the Growth of Pear-Shaped Tetraphymena Cells and Beer Yeast. Chinese Science Bulletin, 29, 235-237.

[37] Jang, J.J., Lee, S.J., Cho, K.J. and Kim, S.H. (1989) Lack of Modifying Effect of Germanium in Rat Hepatic Foci Initiated by Diethylnitrosamine Followed by D-Galactosamine Treatment. Journal of the Korean Cancer Association, 21, 7-11.

[38] Zhang, Y., Wang, B. and Zhang, G. (2004) Study of Anti-Tumor and Mechanism of Organogermanium Poly-Derivatinmves. Carcinogenesis Teratogenesis \& Mutagenesis, 16, 39-42. 
[39] Yang, F., Gong, L., Jin, H., Pi, J., Bai, H., Wang, H., Cai, H., Yang, P. and Cai, J. (2015) Chrysin-Organogermanium (IV) Complex Induced Colo205 Cell ApoptosisAssociated Mitochondrial Function and Anti-Angiogenesis. Scanning, 37, 246-257. https://doi.org/10.1002/sca.21205

[40] Lin, C.H., Chen, T.J. and Chen, S.S. (2009) Functional Changes on Ascending Auditory Pathway in Rats Caused by Germanium Dioxide Exposure: An Electrophysiological Study. Toxicology, 256, 110-117.

[41] Heoun, B.D., Jin, J.T.U.S. and Kang, J.K. (2007) Germanium-Fortified Yeast Activates Macrophage, Nk Cells and B Cells and Inhibits Tumor Progression in Mice. Korean Journal of Microbiology \& Biotechnology, 35, 118-127.

[42] Wang, B.G., Zhang, G.Y., Zhao, L.Y. and Liu, Y. (2002) Inhibiting Effect of Organic Germanium Poly-Acid Derivative on S180 Cells. Journal of Xi an Jiaotong University, 23, 550-551.

[43] Chen, Y. and Shi, Y. (1994) Inhibitory Effect of Ge-132 on the Tumor Lesion of Marek, Disease and Its Mechanism. Chinese Journal of Veterinary Science, 14, 1822.

[44] Kang, K.S., Yun, J.W., Yoon, B.S., Lim, Y.K. and Lee, Y.S. (2001) Preventive Effect of Germanium Dioxide on the Inhibition of Gap Junctional Intercellular Communication by TPA. Cancer Letters, 166, 147-153. https://doi.org/10.1016/S0304-3835(01)00446-3

[45] Liu, C.H., Yao, F.Y., Sun, F.Y., Jiang, J.L. and Xiao, C. (2016) Study on the Inhibition Effect of Caffeic Acid Germanium on the U14 Tumor in Mice and the Cell Apoptosis Mechanisms. Heilongjiang Animal Science \& Veterinary Medicine, 11, 178-180.

[46] Kobayashi, A. and Ogra, Y. (2009) Metabolism of Tellurium, Antimony and Germanium Simultaneously Administered to Rats. Journal of Toxicological Sciences, 34, 295-303. https://doi.org/10.2131/jts.34.295

[47] Wang, Y.X. and Xiao, C. (2006) Research and Progress of Organic Germanium. Jiangxi Journal of Medical Laboratory Sciences, 24, 252-254.

[48] Oh, C., Li, M., Kim, E.H., Park, J.S., Lee, J.C. and Ham S.W. (2011) Cheminform Abstract: Antioxidant and Radical Scavenging Activities of Ascorbic Acid Derivatives Conjugated with Organogermanium. Cheminform, 42, 3513-3514. https://doi.org/10.1002/chin.201116213

[49] Liu, G.Y. and Zhang, D.S. (1997) Effects of Ge-132 on Antioxidant Function of Dairy Cattle. Journal of Gansu Agricultural University, 32, 365-369.

[50] Wang, J.C., Xing, G.S., Hu, W.D., Zhu, T.L., Wang, Q. and Zhao, H. (1994) Effects of Ge-132 on Oxygen Free Radicals and the Lipid Peroxidation Induced by Hydroxyl Free Radical in Vitro. Chinese Pharmaceutical Journal, 29, 24-25.

[51] Yang, M.K. and Kim, Y.G. (1999) Protective Role of Germanium-132 against Paraquat-Induced Oxidative Stress in the Livers of Senescence-Accelerated Mice. Journal of Toxicology and Environmental Health Part A, 58, 289-297. https://doi.org/10.1080/009841099157250

[52] Tang, Z.X. and Shi, Y. (1995) Effects of Ge-132 on Free Radical Metabolism of Parent-Filial Generation in the Laying Hens. I. Effects of Ge-132 on Free Radical Metabolism of Blood and Some Tissues in Laying Hens. Chinese Journal of Veterinary Science, 15, 81-84.

[53] Tang, Z.X. and Shi, Y. (1995b) Effects of Ge-132 on Free Radical Metabolism of Parent-Filial Generation in the Laying Hens II. Vertical Effects of Germanium on Free Radical Metabolism of Blood and Some Tissues of Filial Generation in Laying 
Hens. Chinese Journal of Veterinary Science, 15, 157-161.

[54] Zhang, P.J. and Yu, Y. (1991) Pharmacological Effects of Ge-132. World Pharmacy, 12, 25-26.

[55] Nakamura, T., Nagura, T., Akiba, M., Sato, K., Tokuji, Y., Ohnishi, M. and Osada, K. (2010) Promotive Effects of the Dietary Organic Germanium Poly-Trans-[(2Carboxyethyl) Germasesquioxane] (Ge-132) on the Secretion and Antioxidative Activity of Bile in Rodents. Journal of Health Science, 56, 72-80.

https://doi.org/10.1248/jhs.56.72

[56] Pronai, L. and Arimori, S. (1992) Decreased Plasma Superoxide Scavenging Activity in Immunological Disorders-Carboxyethylgermanium Sesquioxide (Ge-132) as a Promoter of Prednisolone. Biotherapy, 4, 1-8. https://doi.org/10.1007/BF02171703

[57] Harisch, G., Eikemeyer, J. and Schole, J. (1978) The Glutathione Status of the Rat Liver. Cellular and Molecular Life Sciences, 35, 719-720. https://doi.org/10.1007/BF01968201

[58] Xiong, Z.Y. and Yang, H. (2008) Biological Function of Trace Element Germanium and Movement Ability. Journal of Qinghai Normal University (Natural Science), 4, 85-87.

[59] Yuan, Y., Wen, P., Guo, D.X. and Tian, H. (2000) Effects of Organic and Inorganic Germanium on Lipid Metabolism of Broilers. Journal of Shenyang Agricultural University, 31, 203-206.

[60] Tang, Z.X., Shi, Y., Zhao, J.Y., Ma, J., Sun, B.L. and Duan, W.F. (1995) Evaluation of Ge-132 on Laying Hen Performance. Heilongjiang Animal Husbandry and Veterinary Journal, 2, 13-15.

[61] Tang, Z.X., Shi, Y. and Wang, Z.L. (1995) Effects of Ge-132 on Lipid Metabolism of Laying Hens. Heilongiiang Animal Husbandry and Veterinary Journal, 3, 1-5.

[62] Qu, J. (2006) The Biological Functions of Germanium and Its Application in the Poultry Industry. Feed China, 9, 20-26.

[63] Via, S. (1963) The Role of Trace Elements in Hematopoiesis. Terapevticheskii Arkhiv, 35, 3-14.

[64] Sanai, T., Okuda, S., Onoyama, K., Oochi, N., Oh, Y., Kobayashi, K., Shimamatsu, K., Fujimi, S. and Fujishima, M. (1990) Germanium Dioxide. Nephron, 54, 53-60. https://doi.org/10.1159/000185810

[65] Bodansky, M. (1923) The Effect of Germanium Dioxide on Red Cell Regeneration in Experimental Anemia. Experimental Biology \& Medicine, 20, 534-535. https://doi.org/10.3181/00379727-20-266

[66] Kong, T., Qu, Y.S. and Zhu, L.Q. (2007) Biological Function of Trace ElementGermanium. Studies of Trace Elements and Health, 24, 59-60.

[67] Zhang, Y., Cheng, B.Y., Zuo, Y.S., Mao, S.Z., Zhang, J.H., Dai, S.W., Wang, J.R. and Yu, H.W. (1989) Effects of an Organic Germanium Compound (Ge-132) on Hematopoiesis. Journal of First Military Medical University, 9, 207-210.

[68] Schwartz, G.N., Biegel, J.A., Fisher, B. and Klein, I. (1983) Spirogermanium: Effects on Hematopoietic Stem Cells and Survival of Normal and Tumor-Bearing Mice. Experimental Biology and Medicine, 173, 176-180. https://doi.org/10.3181/00379727-173-41627

[69] Xu, C.S., Bi, S.W. and Zhang, X.F. (1996) Trace Elements-Germanium and Human Health. Studies of Trace Elements and Health, 2, 62-63.

[70] Aso, H., Suzuki, F., Yamaguchi, T., Hayashi, Y., Ebina, T. and Ishida, N. (1982) Induction of Interferon and Activation of Nk Cells and Macrophages in Mice by Oral 
Administration of Ge-132, an Organic Germanium Compound. Gan to Kagaku Ryoho Cancer \& Chemotherapy, 9, 1976-1980.

[71] Arimori, S., Watanabe, K., Yoshida, M. and Nagano, T. (1981) Effect of Ge-132 on L1210. Immunomodulation by Microbiol. In: Yamamura, Y., et al., Eds., Products and Related Synthetic Compounds, Elsevier Science Publishing, Amsterdam, 536539.

[72] Park, S.K., Lee, S.W. and Kasumi, T. (1999) Effect of Germanium-132 on the Growth of Lactic Acid Bacteria. Korean Journal of Food Preservation, 6, 506-513.

[73] Mrema, J.E.K., Slavik, M. and Davis, J. (1983) Spirogermanium: A New Drug with Antimalavial Activity against Clorooquine-Resistant Plasmodium Flaciparum. International Journal of Clinical Pharmacology, Therapy \& Toxicology, 21, 167-171.

[74] Feng, X.F. and Jin, W.G. (2006) Advance in Synthesis and Physiological Effect of Germanium Compounds. Food Science and Technology, 31, 177-181.

[75] Slawson, R.M., Van, D.M.I., Lee, H. and Trevors, J.T. (1992) Germanium and Silver Resistance, Accumulation, and Toxicity in Microorganisms. Plasmid, 27, 72. https://doi.org/10.1016/0147-619X(92)90008-X

[76] Dyke, M.I.V., Lee, H. and Trevors, J.T. (1989) Germanium Toxicity in Selected Bacterial and Yeast Strains. Journal of Industrial Microbiology \& Biotechnology, 4, 299-306. https://doi.org/10.1007/BF01577353

[77] Kaars, S.A. (1968) Growth Inhibition of Bacteria by Tributylgermanium Acetate and Its Reversal by Blood Constituents. Antonie van Leeuwenhoek, 34, 85-92. https://doi.org/10.1007/BF02046418

[78] Wen, P., Ji, S.X. and Liu, S.J. (2010) The Effect of Inorganic Germanium on the Lipid Metabolism of Commodity Laying Hens. Heilongjiang Animal Husbandry and Veterinary Journal, 1, 67-68.

[79] Li, J.F. (1993) Growth Promoting Effect and Toxicity of Germanium in Chickens. Archiv für Geflügelkunde, 57, 705-210.

[80] Niu, Z.Y., Jiao, W.M., Liang, X. and Liu, F.Z. (2009) Effects of Carboxyethyl Germanium Sesquioxide (Ge-132) on Growth Performance and Immune Response of Broilers. Journal of the Chinese Cereals and Oils Association, 24, 98-101.

[81] Ha, J.K. (1978) Effects of the Germanium Supplementation (as Germanium Dioxide) on the Performance of Chicken. Journal of the Institute for Agricultural Resource Utilization Gyeongsang University (Korea Republic), 12, 15-18.

[82] Wen, P., Zhao, X.Y., Ao, Y., Qi, G.M. and Liu, Z.Y. (2000) The Effect of Two Types of Germanium Compound on the Production Performance of Meat Chicken. Feed Review, 4, 4-6.

[83] Lee, W.B., Kim, I.H., Hong, J.W., Kwon, O.S., Min, B.J., Shon, K.S. and Jung, Y.K. (2004) Effect of Protein Level and Dietary Germanium Biotite on Egg Production, Egg Quality and Fecal Volatile Fatty Acid in Laying Hens. Korean Journal of Poultry Science, 30, 275-280.

[84] Hong, J.W., Kwon, O.S., Min, B.J., Cho, J.H., Chen, Y.J., Shon, K.S., Kang, J.O. and Kim, I.H. (2006) Influences of Dietary Germanium Colloid on Growth Performance and Hematological Changes in Nursery Pigs. Journal of the Korean Society of International Agriculture, 16, 289-293.

[85] Lee, W.B., Kim, I.H., Hong, J.W., Kwon, O.S. and Min, B.J. (2003) Effects of Dietary Germanium Biotite on Growth Performance and Blood Characteristics in Broiler Chicks. Korean Journal of Poultry Science, 30, 67-72.

[86] Mu, K.H. and Feng, J. (2003) The Study of the Effection of Ge-132 on Cultured Melanocytes. The Chinese Journal of Dermatovenereology, 17, 91-95. 
[87] Feng, X.F. (2005) Germanium and Disease Prevention. Studies of Trace Elements and Health, 22, 62-63.

[88] Ramalho, J., Marques, C., Pereira, P. and Mota, M.C. (1996) Crystallin Composition of Human Cataractous Lens May Be Modulated by Protein Glycation. Graefés Archive for Clinical and Experimental Ophthalmology, 234, S232-S238. https://doi.org/10.1007/bf02343078

[89] Lin, K. (1997) Pathophysiology of Cataracts Copper Ion and Peroxidation in Diabetica. Japanese Journal of Ophthalmology, 41, 130-137. https://doi.org/10.1016/S0021-5155(97)00030-0

[90] Dong, B., Su, X.D., Chen, C.Z. and Wang, H.L. (1998) Analysis of Germanium, Cadmium and Nickel in the Lenses of Senile Cataract Patients. Ophthalmology in China, 7, 190-192.

[91] Unakar, N.J., Johnson, M.J., Cherian M. and Abraham, E.C. (1995) Effect of Germanium-132 on Galactose Cataracts and Glycation in Rats. Experimental Eye Researchm, 61, 155-164. https://doi.org/10.1016/S0014-4835(05)80035-1

[92] Gao, S.Y. (1990) Pharmacology Activity of Lysine Germanium Oxide. Studies of Trace Elements and Health, 3, 3-5.

[93] Sanai, T., Okuda, S., Onoyama, K., Oochi, N., Takaichi, S., Mizuhira, V. and Fujishima, M. (1973) Chronic Tubulointerstitial Changes Induced by Germanium Dioxide in Comparison with Carboxyethylgermanium Sesquioxide. Kidney International, 40, 882-890. https://doi.org/10.1038/ki.1991.289

[94] Matsumoto, H., Jiang, G.Z., Hashimoto, T., Kuboyama, N., Yamane, J., Nonaka, K. and Fujii, A. (2002) Effect of Organic Germanium Compound (Ge-132) on Experimental Osteoporosis in Rats: The Relationship between Transverse Strength and Bone Mineral Density (BMD) or Bone Mineral Content (BMC). Radiology, 1, 10 16.

[95] Matsusaka, T., Fujii, M., Nakano, T., Terai, T., Kurata, A., Imaizumi, M. and Abe, H. (1988) Germanium-Induced Nephropathy: Report of Two Cases and Review of the Literature. Clinical Nephrology, 30, 341-345.

[96] Komuro, T., Kakimoto, N., Katayama, T. and Hazato, T. (1986) Inhibitory Effects of Ge-132 (Carboxyethyl Germanium Sesquioxide) Derivatives on Enkephalin-Degrading Enzymes. Biotechnology and Applied Biochemistry, 8, 379-386.

[97] Fujii, A., Kuboyama, N., Yamane, J., Nakao, S. and Furukawa, Y. (1993) Effect of Organic Germanium Compound (Ge-132) on Experimental Osteoporosis in Rats. General Pharmacology, 24, 1527-1532. https://doi.org/10.1016/0306-3623(93)90447-6

[98] Han, C., Wu, G., Yin, Y. and Shen, M. (1992) Inhibition by Germanium Oxide of the Mutagenicity of Cadmium Chloride in Various Genotoxicity Assays. Food and Chemical Toxicology, 30, 521-524. https://doi.org/10.1016/0278-6915(92)90104-S

[99] Venugopal, B. and Luckey, T.D. (1978) Metal Toxicity in Mammals. Chemical Toxicity of Metals and Metalloids. Plenum Press.

[100] Schroedher, H.A. and Balassa, J.J. (1967) Arsenic, Germanium, Tin and Vanadium in Mice: Effects on Growth, Survival and Tissue Levels. Journal of Nutrition, 92, 245-252.

[101] Hao, W., Xu, Y.Q. and Wang, W.X. (2004) The Present Status of Research on Cancer Cachexia Metabolism. China Cancer, 13, 240-242.

[102] Okada, K., Okagawa, K., Kawakami, K., Kuroda, Y., Morizumi, K., Sato, H., Morita, H., Shimomura, S. and Saito, S. (1989) Renal Failure Caused by Long-Term Use of a Germanium Preparation as an Elixir. Clinical Nephrology, 31, 219-224. 
[103] Krapf, R., Schaffner, T. and Iten, P.X. (1992) Abuse of Germanium Associated with Fatal Lactic Acidosis. Nephron, 62, 351-356. https://doi.org/10.1159/000187072

[104] Kim, K.M., Lim, C.S., Kim, S., Kim, S.H., Park, J.H., Ahn, C., Han, J.S. and Lee, J.S. (1998) Nephropathy and Neuropathy Induced by a Germanium-Containing Compound. Nephrology, Dialysis, Transplantation, 13, 3218-3219. https://doi.org/10.1093/ndt/13.12.3218

[105] Dixon, C., Hagemeister, F., Legha, S. and Bodey, G. (1984) Pulmonary Toxicity Associated with Spirogermanium. Cancer Treatment Reports, 68, 907-908.

[106] Legha, S.S., Ajani, J.A. and Bodey, G.P. (1983) Phase I Study of Spirogermanium Given Daily. Journal of Clinical Oncology Official Journal of the American Society of Clinical Oncology, 1, 331-336.

[107] Li, J.F. (1994) The Growth Promotion Effect and Toxicity of Two Germanium Compounds for Broiler Chickens. Chinese Journal of Animal Nutrition, 6, 23-29.

[108] Arts, J.H.E., Til, H.P., Kuper, C.F., Neve, R. and Swennen, B. (1994) Acute and Subacute Inhalation Toxicity of Germanium Dioxide in Rats. Food and Chemical Toxicology, 32, 1037-1046. https://doi.org/10.1016/0278-6915(94)90144-9

[109] Du, R., Wang, X.J., Ruan, X., Liu, X.S., Qu, Y.Q. and Yang, L.H. (2008) Regulation of Germanium-Enriched Barley Seedling on Immune Function of Mice. Food Science, 29, 578-581.

[110] Wang, Y.S. (2001) Advanced Research of Germanium Nutrition in Poultry. China Feed, 23, 27-28

[111] Niu, Z.Y., Liu, F.Z., Wan, Y.S., Liang, X. and Xie, M. (2001) Effects of Germanium on the Growth of Main Immune Organs in Broilers. Journal of Northwest A\&F University (Natural Science Edition), 10, 41-43.

[112] Tang, Z.X., Chen, Y., Shi, Y., Wang, W. and Zhou, J.P. (1996) Effects of Organogermanium on Development of Immune Organs in Chickens. Journal of Anhui Agricultural University, 23, 145-150.

[113] Zhang, G.L., Lu, S. and Zhong, H.L. (1997) Experimental Study on the Effects of Organic Germanium (Ge-201) on Nonspecific Immunity of Mice. Guangdong Trace Elements Science, 4, 38-39.

[114] Xue, W.L., He, D.D., Li, X.S., Hao, B.H., Zhang, Z.B. and Chen, C.T. (2000) Effect of Zinc, Selenium and Germanium on the Immunity of Mice. Journal of Xí an Medical University, 21, 16-17.

[115] Si, C.P., Dang, X.L., Yu, J., Yang, J. and Yi, M.Y. (1994) The Enhancement Effect of Organic Germanium (Ge-132) on Immune Function. Shanghai Journal of Immunology, 14, 14-15.

[116] Dang, X.L., Si, C.P., Yu, J., Yang, J. and Yi, M.Y. (1992) A Study of the Immunoregulation Effect of Carboxyethyl Germanium Sesgioxide (Ge-132). Journal of Jining Medical University, 15, 27-29.

[117] Gao, Y., Xiao, H.Y., Zhang, Z.B., Hao, B.H. and Xue, W.L. (2001) Effect of Zinc, Selenium and Germanium on the Immunity of Mice. Journal of Hygiene Research, 30 , 252-253.

[118] Jung, M., Shin, M.K., Cha, S.B., Shin, S.W., Yoo, A., Lee, W.J., Park, H.T., Park, J.H., Kim, B., Jung, Y.K. and Yoo, H.S. (2014) Supplementation of Dietary Germanium Biotite Enhances Induction of the Immune Responses by Foot-and-Mouth Disease Vaccine in Cattle. BMC Veterinary Research, 10, 1-10. https://doi.org/10.1186/s12917-014-0179-6

[119] Piao, Y.R., Cui, Y.D., Meng, F.P., Li, Y.X., Jin, X.L. and Cui, F.D. (1993) The Effects of Germanium-132 on Humoral Immunological Function of Mice. Journal of Med- 
ical Science Yanbian University, 16, 93-94.

[120] Li, W.Y., Cheng, L.P., Peng, W., Zhu, Y.F., Gao, H.B. and Wang, Y.F. (1991) Immunomodulation of Organic Germanium (Ge-401) on Antibody Production of Mouse B Lymphocyte. Shanghai Journal of Immunology, 11, 197-199.

[121] Joo, S.S., Won, T.J., Yong, J.L., Min, J.K., Park, S.Y., Lee, S.H., Hwang, K.W. and Lee, Y. (2006) Effect of Geranti Bio-Ge Yeast, a Dried Yeast Containing Biogermanium, on the Production of Antibodies by B Cells. Immune Network, 6, 86-92. https://doi.org/10.4110/in.2006.6.2.86

[122] Suzuki, F., Brutkiewicz, R.R. and Pollard, R.B. (1985) Importance of T-Cells and Macrophages in the Antitumor Activity of Carboxyethylgermanium Sesquioxide (Ge-132). Anticancer research, 5, 479-483.

[123] Si, C.P., Sun, W.D. and Wang, M.H. (1992) Effect of Carboxyethyl Germanium Sesquioxide (Ge-132) on Cellular Immune Function in the Aged. Journal of Jining Medical University, 15, 12-13.

[124] Yu, J. and Si, C.P. (1992) The Effects of Oral Organic Germanium on the Immune Function of RBC. Journal of Jining Medical University, 15, 29-30.

[125] MunakaLa, T., Agai, S., Kumano, K. and Tomita, Y. (1987) Induction of Interferon Production by Natural Killer Cells by Organogermanium Compound-Ge-132. Journal of Interferon Research, 7, 69-76. https://doi.org/10.1089/jir.1987.7.69

[126] Zhang, G.H., Li, W.H., Yang, Q.X., Li, C.R. and Liu, B.Q. (2000) Study of Exogenous Interferons Induced by Ge-132 in Chicken. Heilongjiang Animal Husbandry and Veterinary Journal, 5, 1-4.

[127] Suzuki, F., Brutkiewicz, R.R. and Pollard R.B. (1985) Ability of Sera from Mice Treated with Ge-132, an Organic Germanium Compound, to Inhibit Experimental Murine Ascites Tumours. British Journal of Cancer, 52, 757-763. https://doi.org/10.1038/bjc.1985.254

[128] Ishiwata, Y., Hashimoto, N. and Suzuki, T. (1998) Protection against Concanavalin A-Induced Murine Liver Injury by the Organic Germanium Compound, Propagermanium. Scandinavian Journal of Immunology, 48, 605-614. https://doi.org/10.1046/j.1365-3083.1998.00434.x

\section{Submit or recommend next manuscript to SCIRP and we will provide best service for you:}

Accepting pre-submission inquiries through Email, Facebook, LinkedIn, Twitter, etc. A wide selection of journals (inclusive of 9 subjects, more than 200 journals) Providing 24-hour high-quality service User-friendly online submission system Fair and swift peer-review system Efficient typesetting and proofreading procedure Display of the result of downloads and visits, as well as the number of cited articles Maximum dissemination of your research work

Submit your manuscript at: http://papersubmission.scirp.org/ Or contact jbm@scirp.org 